\title{
Performance Analysis of Grid-Connected CIGS PV Solar System and Comparison with PVsyst Simulation Program
}

\author{
Naseer K.Kasim *, Hazim H.Hussain **t, Alaa N.Abed*** \\ * Al-Hussein University College, Ministry of Electricity/Training and Energy Research Office, Ministry of Electricity, \\ Baghdad-Iraq \\ ** Department of Atmospheric sciences, College of sciences, AL-Mustansiriyah University , Baghdad-Iraq \\ *** Department of Atmospheric sciences, College of sciences, AL-Mustansiriyah University, Baghdad-Iraq \\ (irss2004@yahoo.com, hazimonly1@yahoo.co.uk,wiseman_1988@yahoo.com)
}

¥ Alaa N.Abed; Hazim H.Hussain, Baghdad-Iraq, Tel: +964 7706395463,

Received: 31.05 .2019 Accepted:23.06.2019

\begin{abstract}
CIGS is the thin film technology (second generation) fabricated from Copper-Indium Gallium Selenide. This research displays the performance assessment of a $5 \mathrm{kWp}$ CIGS grid-connected PV Solar system. CIGS system installed at alMansour Company, Iraq-Baghdad (latitude $33.3^{\circ} \mathrm{N}$, longitude $44.4^{\circ} \mathrm{E}$ and $41 \mathrm{~m}$ above the sea level). The current paper presents the performance analysis of CIGS system (real system) and the comparison with PVsyst simulation program to find out how close are the CIGS system approaches perfect system (PVsyst) under Baghdad climate. The CIGS system was monitored during the year of 2017. The daily average of array, reference and final yields for real and PVsyst systems were $5 \mathrm{kWh} / \mathrm{kWp}$ (h/day), $6.1 \mathrm{kWh} / \mathrm{kWp}$ and $4.85 \mathrm{kWh} / \mathrm{kWp}$, and $5.46 \mathrm{kWh} / \mathrm{kWp}$ (h/day), $6.3 \mathrm{kWh} / \mathrm{kWp}$ and $5.3 \mathrm{kWh} / \mathrm{kWp}$ respectively. The annual energy yield from real and PVsyst systems are $1781.8 \mathrm{kWh} / \mathrm{kWp} /$ year and $1924 \mathrm{kWh} / \mathrm{kWp} /$ year respectively. The annual energy output from real and PVsyst systems are $8820.2 \mathrm{kWh}$ and $9538.5 \mathrm{kWh}$ respectively. The annual global horizontal solar irradiation (GHI) received in Baghdad of $1986.4 \mathrm{kWh} / \mathrm{m}^{2}$. The yearly daily average of system and array losses for real and PVsyst systems were $0.18 \mathrm{kWh} / \mathrm{kWp} /$ day and $0.18 \mathrm{kWh} / \mathrm{kWp} /$ day, and $1.1 \mathrm{kWh} / \mathrm{kWp} /$ day and 0.84 $\mathrm{kWh} / \mathrm{kWp} /$ day respectively. The yearly average of array, system and inverter efficiencies for real and PVsyst systems were $12.7 \%, 12.1 \%$ and $96.47 \%$, and $13.18 \%, 12.72$ and 97 respectively. The yearly average of the capacity factor and performance ratio for real and PVsyst systems were $20.4 \%$ and $80.2 \%$, and $22 \%$ and $83 \%$ respectively. These values indicate very good performance for CIGS PV solar system fixed in Baghdad city. The comparison between PVsyst and CIGS will take place in results and discussion.
\end{abstract}

Keywords Grid-connected, CIGS, Solar PV, performance, PVsyst, solar cell.

\section{Introduction}

Solar energy is a green energy, which can be used to accomplish worldwide energy needs. The energy demands are increasing while the fossil fuel resources which dominate most general energy systems are limited and forecast to become less and more expensive in future [1]. Renewable energy resources exist over wide geographical areas, in contrast to other energy sources, which are concentrated in a limited number of countries like oil and gas. Rapid deployment of renewable energy and energy efficiency is resulting in significant energy security, climate change mitigation, and economic benefits. The transition from first generation technology silicon solar cells to the second generation (CIGS ) cells (thin film technology) is a quantum leap in the field of photovoltaic production. The materials of PV solar panels comprise: the Crystalline Silicon (polycrystalline and Monocrystalline), (Amorphous silicon (a-Si), Copper-Indium Gallium-Selenide (CIGS), Cadmium Telluride (CdTe)). Silicon panels make up the largest part in the market, with an estimation of $90 \%$ of market share of panels while thin films make up less than $10 \%$ [2]. PV solar cells made of silicon are commonly called first generation technology. The market at current is on the brink of 
transferring to technology of a second generation (thin film). Technology of Thin film introduces more benefits as a big drop in material costs in comparison with the costs of the silicon wafers that need, as well as, thin film solar PV cells Technology have little temperature coefficient[3]. Silicon solar cells efficiency at standard test conditions $\left(1000 \mathrm{~W} / \mathrm{m}^{2}\right.$, $25^{\circ}$ Cand AM: 1.5$)$ close to $24.4 \%$ for Monocrystalline, $19.8 \%$ for a polycrystalline and $10.2 \%$ for amorphous $[4,5$, 6], while efficiency of (CdTe) and (CIGS) are $16.5 \%$ and $19.9 \%$, respectively $[7,8]$. More researches were conducted throughout the world, about the performance analysis and characteristics of the on-grid PV solar systems, for example Li studied an On-grid PV system in city of Hong Kong and proved that the energy payback duration was about 8.9 years [9]. Canete et al. studied four different PV panel technologies which are $\mathrm{CdTe}$, amorphous silicon, polycrystalline silicon, and microcrystalline silicon and estimated of incoming solar radiation for a year in Spain and it showed that the thin-films were more productive than other panels [10]. Mabvuto. M , Kivanc .B, Numan .S , Kolay .Ü, were conducted a research about Comparative Performance Analysis of 20kWp Grid Connected for different PV solar Technologies (CIS, C-Si, $\mathrm{CdTe}$ ) in Zambia, The results showed that CdTe has higher performance of $80.17 \%$, followed by CIS of $73.97 \%$, and CSi the least of $72.24 \%$. the monthly average solar irradiation of $167 \mathrm{kWh} / \mathrm{m} 2$ with the annual average temperature of $26 \mathrm{Co}$ [11].Naseer, et al. conducted a research about the evaluation performance through depositing and the treatment of dust by tracking the panel and they found that when the tracker panel bend down to capture the solar radiation at sunset the dust deposits down because of gravity $[12,13,14]$. Shaharin .A, Atul .K, Mior .M, Mohammed .A, were conducted research about Influence of Dirt Accumulation on Performance of PV Panels, and they found that the external resistance could reduce the photovoltaic performance by up to $85 \%$ [15]. The main goal of this research is to assessing the performance of $5 \mathrm{kWp}$ CIGS (thin film) grid-tied PV system in a one year under Baghdad-Iraq climate conditions.

\section{Real and simulation PV solar system details}

PVsyst simulation program has same real options in terms of location, nominal power, tilt angle, azimuth angle, latitude, longitude and panel technology. The PV solar system lies in north Baghdad/Al-kadhumia city in Al-Mansour Factory in latitude $33.3^{\circ} \mathrm{N}$ and longitude $44.4^{\circ} \mathrm{E}$.

Table 1.Real and PVsyst solar PV system details

\begin{tabular}{|l|l|l|}
\hline System & Simulation System & Real System \\
\hline Panel model & TS-165C2 CIGS & $\begin{array}{l}\text { TS-165C2 } \\
\text { CIGS }\end{array}$ \\
\hline panels Number of & 30 & 30 \\
\hline Inverter model & SMA SB-5000T-21 & $\begin{array}{l}\text { SMA SB- } \\
5000 \mathrm{~T}-21\end{array}$ \\
\hline $\begin{array}{l}\text { Inverter Size (kWp } \\
)\end{array}$ & 5.30 & 5.30 \\
\hline Inverter efficiency & $97 \%$ & $97 \%$ \\
\hline System Size $(\mathrm{kWp})$ & 5 & 5 \\
\hline Tilt Angle & $15 / 50 \mathrm{Sum} / \mathrm{win}$ & $15 / 50 \mathrm{Sum} / \mathrm{win}$ \\
\hline
\end{tabular}




$$
Y_{r}=\frac{H_{T}}{H_{R}}\left(k W h / k W_{P}\right)
$$

Where: $H_{T}$ and $H_{R}$ are the solar irradiation in-collimated plane and reference Irradiance respectively.

\subsection{System and Array Energy losses:}

Array losses $\left(\mathrm{L}_{\mathrm{A}}\right)$ are show the losses caused by array working that exhibit disability of the array to totally convert the available solar insolation (irradiation) to electricity. The array losses are the difference between the $\mathrm{Y}_{\mathrm{R}}$ and the $\mathrm{Y}_{\mathrm{A}}$. It is calculated as [16]:

$L_{A}=Y_{R}-Y_{A}\left(k W h / k W_{p}\right)$.

The system energy losses $\left(L_{s}\right)$ are caused by losses in converting the direct current energy to alternating power (DC to $\mathrm{AC}$ ) via the inverter. It is calculated as:

$$
L_{s}=Y_{A}-Y_{F}\left(k W h / k W_{p}\right) \text {. }
$$

\subsection{System Efficiencies}

The PV solar system efficiency is classified into following: Array, System and Inverter Efficiencies. these efficiencies can be calculated annually, monthly, daily and hourly. The system efficiency ( $\eta$ sys) is built on the alternating current power product and the array efficiency $(\eta \mathrm{PV})$ is built on the direct current power product. The array efficiency is the ratio The array efficiency is the ratio of daily, monthly or annually average of array energy product (DC) to the total daily, monthly or annualy average of solar irradiation in-collimated plane multiplied by the area of the PV solar array [16]. The PV solar array efficiency is given as:

$\eta_{p V}=\frac{100 * E_{D C}}{H_{t} * A_{m 1}} \%$

where $A_{m}=$ array area $\left(\mathrm{m}^{2}\right), \mathrm{Ht}=$ solar irradiation collimated plane. it is calculated as:

$\mathrm{\eta}_{S Y S}=\frac{100 * E_{A C}}{H_{t} * A_{m}} \%$

The inverter efficiency is calculated as:

$\eta_{I N V}=\frac{100 * E_{A C}}{E_{D C}} \%$

\subsection{Performance Ratio (PR)}

(PR) appear all PV solar system losses. Value of PR shows how close system approaches perfect performance through actual work and permits comparison of Photovoltaic solar systems each other irrespective of angle, tilt,orientation, location and their rated power capacity [17]. PR is calculated as the ratio of the $\left(\mathbf{Y}_{\mathbf{F}}\right)$ over (Yr) of the PV solar system, it given as[18].

$P_{R}=\frac{Y_{F}}{Y_{T}} \%$

\subsection{Capacity Factor (CF)}

$\mathrm{CF}$ is a way used to assess the energy produced by an PV solar system and is calculated as the ratio of Alternating Current energy produced by the photovoltaic solar system divided by a specfied duration (usually month or one year) multiplied by rated value (nominal) of the PV solar system. The yearly capacity factor of the PV solar system is calculated as following [18]:

$C_{F}=\frac{E_{\text {AC }}}{P_{P V_{\text {N }} \text { rated }} * 8760}$

\subsection{Energy Output}

The overall energy is defined as the quantity of AC power produced by the PV solar system in a specified duration. The hourly, daily and monthly energy product is calculated respectively as follow :[19]

$\mathrm{E}_{\mathrm{AC}, \mathrm{h}}=\sum_{t=1}^{60} \mathrm{EAC}, \mathrm{t}$

$\mathrm{E}_{\mathrm{AC}, \mathrm{d}}=\sum_{h=1}^{24} \mathrm{EAC}_{1} \mathrm{~h}$

$\mathrm{E}_{\mathrm{AC}, \mathrm{m}}=\sum_{d=1}^{N} \mathrm{EAC}_{,} \mathrm{d}$

Where: EAC,t is AC Energy produced at minutes; EAC,h is AC Energy produced at hour; EAC,d is AC Energy produced at day; $E_{A C, m}$ is the monthly AC Energy produced and $\mathrm{N}$ represent the days number in the month.

\subsection{Real and PVsyst Data}

Table 2 content real and PVsyst data are used in this manuscript. In this table is noticed the data values of PVsyst system lager than real system that because PVsyst system not effects in atmospheric phenomena like cloud, rain and dust.

Table 1.Real and PVsyst solar PV system Data

\begin{tabular}{|c|c|c|c|c|l|l|l|l|}
\hline \multicolumn{1}{|l|}{ PV syst System Details } & \multicolumn{1}{|l|}{ Real System Details } \\
\hline Month & $\begin{array}{c}\text { T Amb } \\
{ }^{\circ} \mathbf{C}\end{array}$ & $\begin{array}{c}\text { GlobInc } \\
\mathrm{kWh} / \mathrm{m}^{2}\end{array}$ & $\begin{array}{c}\text { E_Grid } \\
\mathrm{kWh}\end{array}$ & $\mathrm{PR}^{2}$ & $\begin{array}{c}\text { GlobInc } \\
\mathrm{kWh} / \mathrm{m}^{2}\end{array}$ & $\begin{array}{c}\text { T Amb } \\
{ }^{\circ} \mathbf{C}\end{array}$ & $\begin{array}{c}\text { E_Grid } \\
\mathrm{kWh}\end{array}$ & PR\% \\
\hline January & 7.98 & 156.5 & 690.3 & 89. & 145.88 & 16.8 & 580.02 & 80.3 \\
\hline February & 11.13 & 164.2 & 713.9 & 87.7 & 156.8 & 18.5 & 642.41 & 82.7 \\
\hline
\end{tabular}


INTERNATIONAL JOURNAL OF SMART GRID

N. K. Kasim et al., Vol.3, No.4, December, 2019

\begin{tabular}{|l|l|l|l|l|l|l|l|l|}
\hline March & 16.05 & 184.0 & 781.0 & 85.7 & 174 & 23.9 & 720.92 & 83.7 \\
\hline April & 20.59 & 194.0 & 809.7 & 84.2 & 183.6 & 28.8 & 749.91 & 82.5 \\
\hline May & 26.65 & 215.9 & 877.7 & 82.0 & 201.1 & 33.6 & 789.66 & 79.3 \\
\hline June & 31.40 & 217.4 & 865.9 & 80.3 & 231.7 & 40 & 887.97 & 77.4 \\
\hline July & 34.26 & 220.2 & 869.9 & 79.7 & 231.1 & 44 & 876.15 & 76.5 \\
\hline August & 33.77 & 223.4 & 883.6 & 79.8 & 223.5 & 43 & 871.96 & 78.8 \\
\hline September & 28.74 & 206.9 & 835.1 & 81.5 & 193 & 40 & 765.14 & 80.1 \\
\hline October & 23.84 & 198.3 & 820.7 & 83.5 & 182.6 & 34 & 731.08 & 81 \\
\hline November & 14.70 & 171.3 & 737.7 & 86.9 & 150 & 22 & 601.50 & 81 \\
\hline December & 9.86 & 148.9 & 652.8 & 88.4 & 141.5 & 19 & 560.41 & 80 \\
\hline
\end{tabular}

Where: GlobInc GlobInc is Global incident in coll. Plane.

$\mathrm{T}$ Amb is Ambient Temperature.

E_Grid is Energy injected into grid

$\mathrm{PR}$ is Performance Ratio

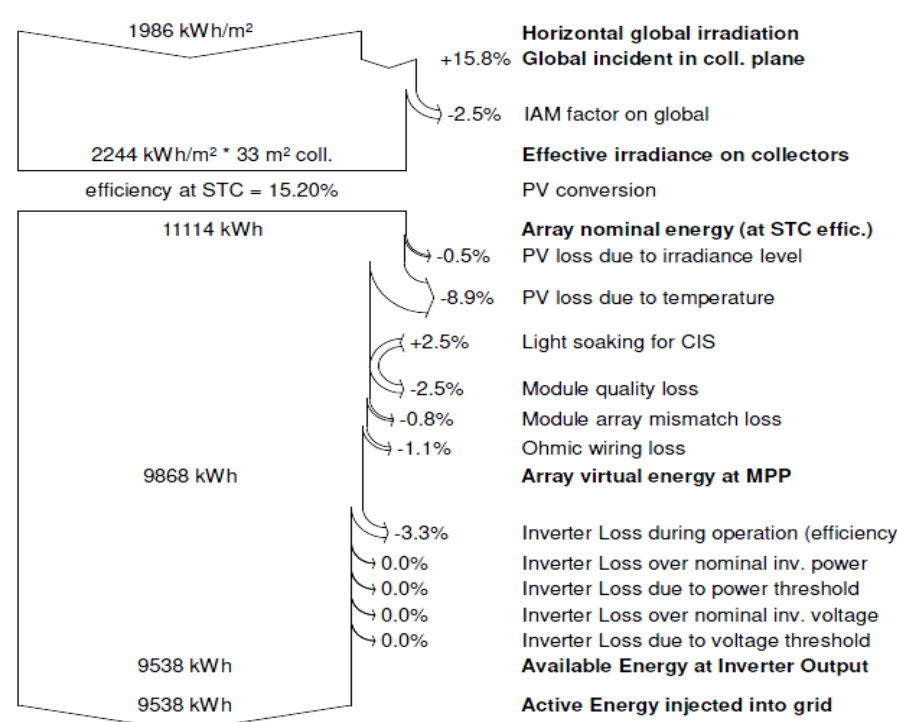

FIG 3. Loss diagram over the whole year
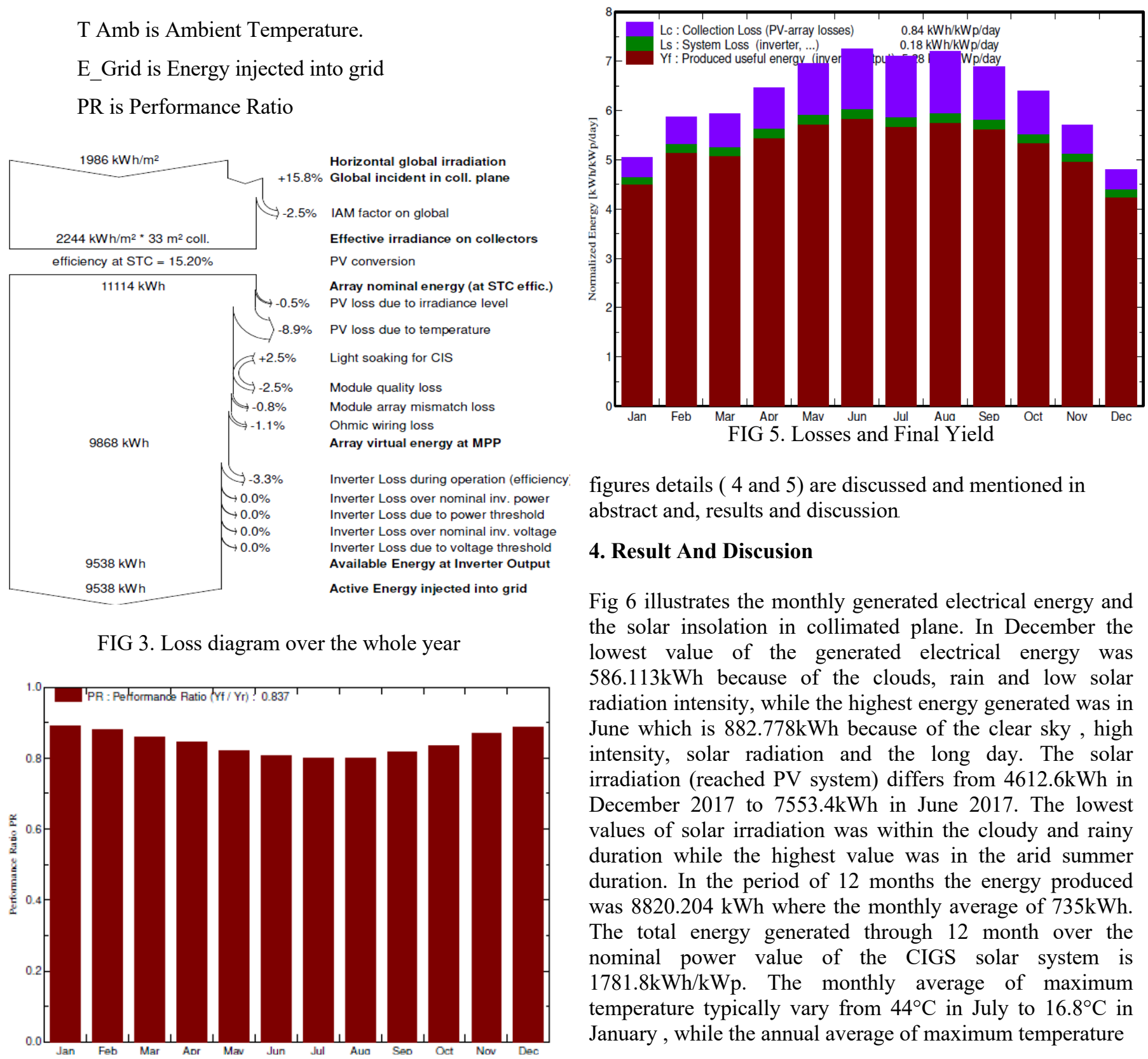

figures details ( 4 and 5) are discussed and mentioned in abstract and, results and discussion

\section{Result And Discusion}

Fig 6 illustrates the monthly generated electrical energy and the solar insolation in collimated plane. In December the lowest value of the generated electrical energy was $586.113 \mathrm{kWh}$ because of the clouds, rain and low solar radiation intensity, while the highest energy generated was in June which is $882.778 \mathrm{kWh}$ because of the clear sky, high intensity, solar radiation and the long day. The solar irradiation (reached PV system) differs from 4612.6kWh in December 2017 to $7553.4 \mathrm{kWh}$ in June 2017. The lowest values of solar irradiation was within the cloudy and rainy duration while the highest value was in the arid summer duration. In the period of 12 months the energy produced was $8820.204 \mathrm{kWh}$ where the monthly average of $735 \mathrm{kWh}$. The total energy generated through 12 month over the nominal power value of the CIGS solar system is $1781.8 \mathrm{kWh} / \mathrm{kWp}$. The monthly average of maximum temperature typically vary from $44^{\circ} \mathrm{C}$ in July to $16.8^{\circ} \mathrm{C}$ in January, while the annual average of maximum temperature

FIG 4. PVsyst Performance Ratio 
was $30^{\circ} \mathrm{C}$. In spite of the high temperature in June which in turns reduce the energy produced from the PV solar system, this month it has the highest value of electrical energy produced because it has the largest number of sunrise hours (15 hours) and highest intensity of solar radiation. In the other side, the lowest value of electrical energy produced was in December because it has the lowest number of sunrise hours ( 9 hours) and lowest intensity of solar radiation. In comparison, the annual average of energy produced from CIGS PV solar system (real system) which equal to $(8820.204 \mathrm{kWh})$ at annual average of ambient temperature $\left(30^{\circ} \mathrm{C}\right)$ with the PVsyst simulation program which is the clear sky model and it is a software package used for the data analysis, sizing and study of completed $P V$ solar systems. PVsyst deals with DC-grid, grid-tied, stand-alone, and pumping and $P V$ solar systems. This software comprise spacious of meteorological databases, PV solar Systems Components databases and add to general solar energy Tools . PVsyst version was used in current study is 6.5.1. [20]. The annual average of energy produced from the simulation program (PVsyst) was $(9692 \mathrm{kWh})$ at annual average of air temperature of $21.5^{\circ} \mathrm{C}$. Obviously the difference is not great although the real system works at high temperatures and is affected by rain, cloud and dust in the contrary of PVsyst simulation program results which are built on low temperatures and they are not affected by rain, cloud and dust, this means the practical measurement results were very good because they are very close to PVsyst simulation results.

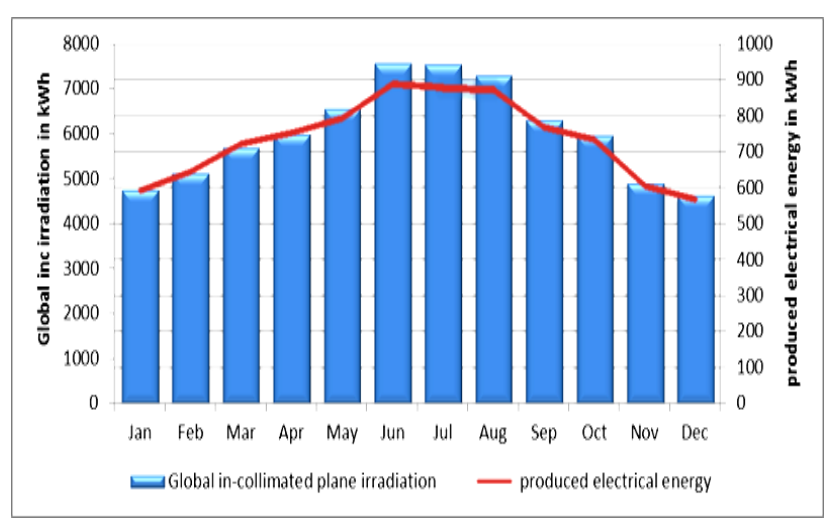

Fig 6.Monthly product of electrical Energy and Solar irradiation in-collimated plane of real system.

The monthly average values of array yield, final yield and daily reference yield were presented in Fig 7 . It can be noticed that the lowest values were documented in winter duration in December and January. In December 2017, the array yield ,final yield and reference yield were $4.1 \mathrm{kWh} / \mathrm{kWp} /$ day,3.9kWh/kWp/dayn and $4.7 \mathrm{kWh} / \mathrm{kWp} /$ day, respectively while the highest values of array yield, final yield and reference yield were in June of $6.13 \mathrm{kWh} / \mathrm{kWp} /$ day, $5.9 \mathrm{kWh} / \mathrm{kWp} /$ day and $7.72 \mathrm{kWh} / \mathrm{kWp} /$ day respectively. The annual average of array yield, final yield and reference yield for throughout of 2017 year were $5 \mathrm{kWh} / \mathrm{kWp} /$ day, $4.85 \mathrm{kWh} / \mathrm{kWp} /$ day and $6.1 \mathrm{kWh} / \mathrm{kWp} /$ day respectively. Vignola et al.[21] noticed that inverter efficiency drops nearly $1 \%$ for about each $12^{\circ} \mathrm{C}$ rise in air temperature. when comparing the final yield of real system at annual average temperature during the course of a 2017 year which is $30^{\circ} \mathrm{C}$ with the final yield of simulation program (PVsyst) at annual average temperature during the course of a 2017 year which is $21.5^{\circ} \mathrm{C}$,It was found that the annual average of the final yield of CIGS system and simulated results for the period of 2017 were $4.85 \mathrm{kWh} / \mathrm{kWp} /$ day and $5.33 \mathrm{kWh} / \mathrm{kWp} /$ day respectively, this shows small difference between CIGS system and PVsyst system. This simulation program it is a clear sky model so it doesn't taking the effect of the atmospheric condition as dust, cloud and rain in consideration, However, the PV solar CIGS system works very well under the Baghdad climate and can be considered a promising technology for use in Iraq despite the hot climate of Iraq in the summer.

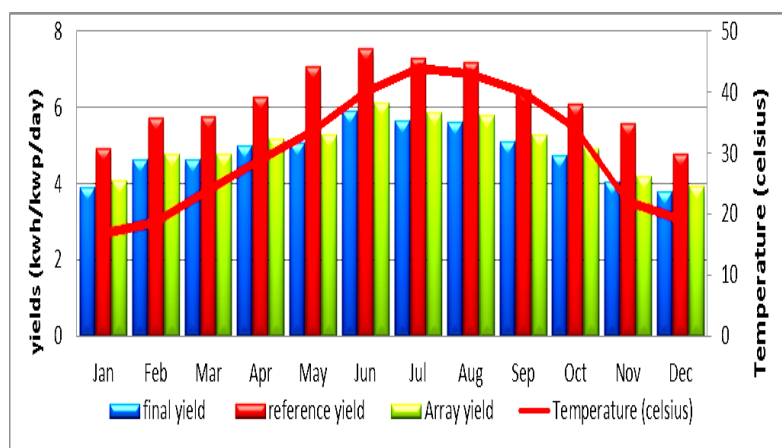

Fig 7. Monthly average of daily yields of real system.

Fig.8 illustrates the monthly average of daily losses to overall, array and system. In July, it was noticed that the maximum value of monthly average of daily array losses of $1.6 \mathrm{kWh} / \mathrm{kWp} /$ day that due to high air temperature and the minimum value which was recorded in the January and December months of $0.61 \mathrm{kWh} / \mathrm{kWp} /$ day, these values make up $21.4 \%$ and $12.9 \%$ of the monthly daily average of reference yield respectively. Losses in the system (represent inverter losses) diverse from

0.14

$\mathrm{kWh} / \mathrm{kWp} /$ day in December to $0.22 \mathrm{kWh} / \mathrm{kWp} /$ day in June, as displayed in Fig.4, that because of large conversion from DC to AC current due to a large solar irradiance intensity incident on panels in June .These values make up 3\% and $2.9 \%$ of the daily reference yield respectively. When it is compared, the yearly average of daily array losses of the real system of $1.1 \mathrm{kWh} / \mathrm{kWp} /$ year at yearly average of air temperature of $30^{\circ} \mathrm{C}$ with daily array losses value of PVsyst simulation program of $0.722 \mathrm{kWh} / \mathrm{kWp} /$ year at yearly average air temperature of $21.5^{\circ} \mathrm{C}$, It was found that the difference is only $0.47 \mathrm{kWh} / \mathrm{kWp} /$ year . the yearly average of daily system losses for real system and simulated system were $0.181 \mathrm{kWh} / \mathrm{kWp} /$ year and $0.18 \mathrm{kWh} / \mathrm{kWp} /$ year respectively, this convergence in daily system losses between real and simulated systems due to approaching the inerter efficiencies to two systems because inverter of real system was installed indoor. The maximum value of overall losses was recorded in July of $1.82 \mathrm{kWh} / \mathrm{kWp} /$ day and the minimum value was recorded in January and December of $0.77 \mathrm{kWh} / \mathrm{kWp} /$ day, These values make up $24.4 \%$ and $16.8 \%$ from daily reference yields respectively. The yearly average of daily losses to overall, array and system were $1.3 \mathrm{kWh} / \mathrm{kWp} /$ day, 
$1.1 \mathrm{kWh} / \mathrm{kWp} /$ day and $0.194 \mathrm{kWh} / \mathrm{kWp} /$ day, respectively. Overall losses equal (array losses + system losses).

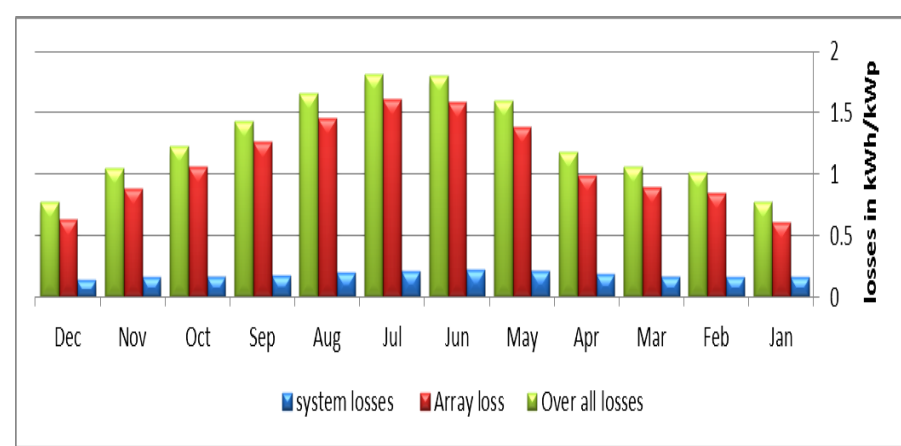

Fig 8. Monthly average of daily losses to overall, array and system of real system.

Fig.9 shows The monthly average of inverter, system and array efficiencies during the observing duration. The annual average values of efficiencies are $96.6 \%, 12.1 \%$ and $12.7 \%$ respectively. A maximum value of the inverter, system and array efficiency were in January of $96.7 \%, 12.7 \%$ and $13.1 \%$ respectively and the minimum efficiency of inverter, system and array were in July of $96.6 \%, 11.5 \%$ and $12 \%$ while the annual average of inverter, array and system efficiency of PVsyst simulation program at annual average temperature $21.5^{\circ} \mathrm{C}$ were $97 \% 13.16 \%$ and $12.72 \%$ this means the measured results (real data) are very close to PVsyst results in spite of the CIGS system works at annual average temperature of $30^{\circ} \mathrm{C}$.

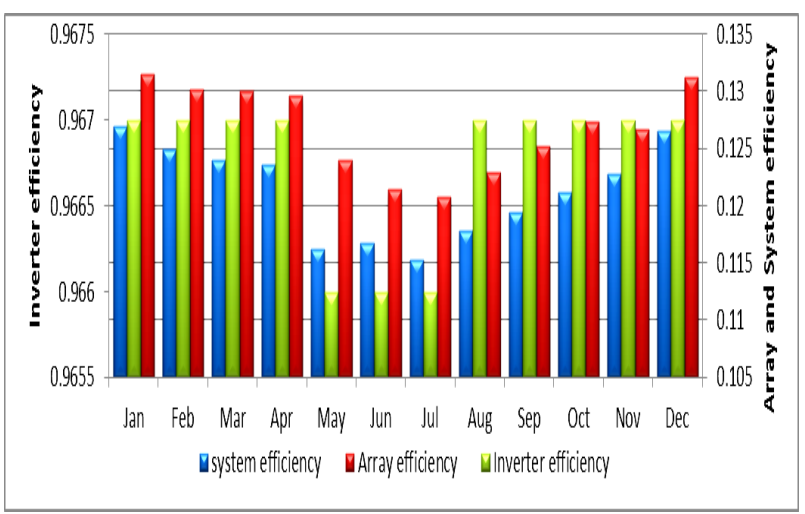

Fig 9. Monthly average of inverter, system and array efficiency of real system.

Fig. 10 shows the monthly average capacity factor and performance ratio. The yearly average of PR for the real system was $80.3 \%$ where the maximum value of PR was in January and December of $83.8 \%$ and the minimum value was $76 \%$ in July month.PR is indicator for how near the real system from perfect performance through actual operating [22].The PR of the present system drop in month May, June, July and August under the average due to arising temperature in these months. when compared the yearly average PR of the real system which equal to 80.3 at annual average temperature which is $30^{\circ} \mathrm{C}$ with annual average performance (PR) of PVsyst simulation program which equal to $83.7 \%$ at annual average temperature which is $21.5^{\circ} \mathrm{C}$, it was found that the measured PR (real) very close to simulation program PR in spite of the simulation program works at air temperature less than air temperature at which real system (CIGS system) works, so it can be considered PR of real system very well in spite of the high air temperature effect, this means this real system is not significantly affected in high air temperature.

The yearly average of capacity factor (CF) is $20.4 \%$, where the maximum value of $24.8 \%$ in June and a minimum value of $16 \%$ in December. $\mathrm{CF}$ is the indicator exhibits the time magnitude in percentage at which the generation of the PV solar system in maximum capacity, Therefore the system generation in its full capacity roughly 92 days or $2208 \mathrm{~h}$ per year (June, July and august). The CF has a direct implication on the cost of electricity generation. Therefore the PR and CF are a very significant parameters to assess grid-connected PV solar systems. In India CF throughout the state contrasts between $20 \%$ and $16 \%$ [23]. In Mauritania capacity factor throughout the country contrasts from a $11.7 \%$ to $20.5 \%$ [22]. In Malaysia CF of the PV system was $10.47 \%$. in our system the annual average capacity factor varies between $16 \%$ and $24.8 \%$ this means it is best capacity factor than all mentioned above in spite of arising temperature than all mentioned above and when compared the annual average capacity factor of this real system (CIGS) of $20.3 \%$ with the annual average capacity factor of PVsyst simulation program of $22 \%$,was found that the difference small (only 1.7\%) in spite of the real system (CIGS) works at air temperature bigger than at which PVsyst program works and this program not takes cloud, rain and dust into consideration. There is a way used to improve the performance ratio and capacity factor of the PV solar modules by using optical reflectors and cooling [24].

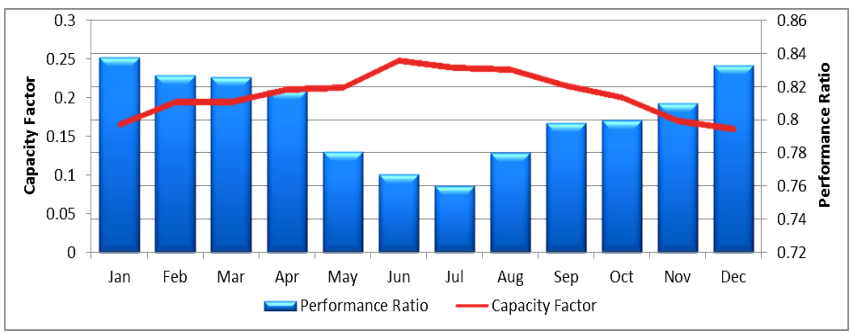

Fig 10. Performance ratio and capacity factor of real system.

\section{Conclusion}

In current study was found the following conclusions:

- Was found there are small difference between PVsyst simulation program and current CIGS system values in spite of PVsyst works at annual average temperature of $21^{\circ} \mathrm{C}$ and CIGS system at $30^{\circ} \mathrm{C}$.

- In the terms of efficiency CIGS system very close to efficiency of PVsyst simulation program as mentioned in results and discussion above and also the losses very close between the two systems.

- The conclusions above illustrate clearly how the CIGS technology results close to PVsyst results, where the PVsyst regard ideal system because it is not affected by cloud, rain and dust and works at annual average temperature of $21.5^{\circ} \mathrm{C}$ on the contrary of CIGS system (real measured results) which is affected by cloud, rain and dust and works at annual average temperature $\left(30^{\circ} \mathrm{C}\right)$, this means the real 
system (CIGS) is not significantly affected by hot Iraqi climate.

- In the terms of losses there is approaching between CIGS (real) system and PVsyst program in cold season while the difference increases small in hot season namely the overall losses of CIGS becomes slightly bigger than PVsyst.

- According to the four points aforementioned can say that the CIGS technology is promising and very suitable for hotter climates in Iraq and Arabian Gulf.

\section{Acknowledgements}

All the authors are grateful to AL-Mansour Factory/ALZawraa Company and Training \& Energy Research Office / Ministry of Electricity for their great efforts in support and the implementation of this work.

\section{References}

[1] H. Ali , A. Marc, A Critical Review of Thermochemical Energy Storage Systems, The Open Renewable Energy Journal , Vol.4 ,no. 45, pp.42-46, 2011

[2]International Energy Agency (IEA), Technology Roadmap Solar Photovoltaic Energy, 2014. www.iea.org.

[3] M . Green, . Emery, Y . Hishikawa, W. Warta, E. Dunlop , "Solar cell efficiency tables (Version 39). Progress in Photovoltaics", vol 20, pp. 12-20, DOI: 10.1002/pip.2163 , 29 December 2011.

[4] J. Zhao, A. Wang, "Green MA. 19.8\% efficient honeycomb textured multi-crystalline and $24.4 \%$ Monocrystalline silicon solar cells", Applied Physics Letters, vol 73, pp.1991-3. July 1998.

[5] T .Matsui, H. Sai, , T .Suezaki, M. Matsumoto, K. Saito, I .Yoshida, M. Kondo, "Development of highly stable and efficient amorphous silicon based solar cells". Proc. 28th European Photovoltaic Solar Energy Conference, pp. 22132217. 2013.

[6] X. Wu, J. Keane, R. Dhere, C. DeHart, , A. Duda, , T. Gessert, S. Asher, D. Levi , P. Sheldon , "16.5\%-efficient CdS/CdTe Polycrystalline Thin-Film Solar Cell”, Conf. Proceedings 17th European Photovoltaic Solar Energy Conference, Munich, pp.995-1000. 22-26, October 2001.

[7] M. J. Keevers, T.L. Young, U.Schubert, M.A. Green “10 $\%$ Efficient CSG Minimodules",22nd European Photovoltaic Solar Energy Conference (PVSEC), Milan, Italy, 3-7, Sept 2007.

[8] H.W.Danny, K.L.Cheung, N.T. Tony, W.H Chan , " A study of grid-connected photovoltaic PV system in Hong
Kong", Applied Energy, Vol. 90, no. 1, pp. 122-127, February 2012,

[9] C. Cañete, J .Carretero, M. Sidrach, "Energy performance of different photovoltaic module technologies under outdoor conditions". Energy, vol.65, pp.295-302, 2014.

[10] H. A. Kazem, M. T. Chaichan, "Experimental effect of dust physical properties on photovoltaic module in northern Oman," Solar Energy, vol. 139, pp. 68-80. 2016.

[11] M. Mabvuto, B. Kivanc, S. Numan , Ü. Kolay, "Comparative Performance Analysis of PV Technologies for Application in Grid Connected PV Systems in Eastern Province of Zambia", Ege University, Solar Energy Institute, Department of Solar Energy Technologies, Pp.1-7, 2010.

[12] K.K. Abbas, A. Al-Wattar, N. K.Kasim, "New Technique for Treatment of the dust accumulation from PV solar panels surface", Iraqi Journal of Physics, vol. 8, no 12, pp.54-59, 2010

[13] N.K. Kasim, A.F. Atwan, J.S.Hameed, " Performance Evaluation of Well Known Commercially Solar Modules under Real Conditions of Iraqi Environments, Baghdad Science Journal, (physics conference), vole8, no. 2pp.658665, 2011.

[14] N.K. Kasim, A.J. Al-Wattar, , K.K. Abbas , A.F. Atwan,.." Evaluating the performance of fixed solar panels relative to the tracking Solar Panels under natural deposition of dust" ,Baghdad Science Journal, vol. 7, pp.244-255, February 2019.

[15] A. Shaharin, K. Atul, M. Mior, A. Mohammed, " Influence of Dirt Accumulation on Performance of PV Panels ", The International Conference on Technologies and Materials for Renewable Energy, Environment and Sustainability, TMREES14, Available online at www.sciencedirect.com, Energy Procedia, vol. 5 ,pp. 50 56, 24 July 2014.

[16] S. Wittkopf, S. Valliappan, L. Ang, K. Liu, S. Cheng, "Analytical performance monitoring of a $142.5 \mathrm{kWp}$ gridconnected rooftop BIPV system in Singapore", Renew Energy, vol. 47,pp.9-20, 2012.

[17] T. Ozden, , B. Akinoglu, , R. Turan, "Long term outdoor performance of three different on-grid PV arrays in central Anatolia - an extended analysis", Renew Energy, vol. 101, pp.182-95, 2017.

[18] K. Padmavathim, S. Daniel, "Performance analysis of a 3 MWp grid connected solar photovoltaic power plant in India", Energy Sustain De, vol17, pp.615-25, 2013 
[19] B. Sohanpal, " Design, Fabrication and Performance Analysis of Close Type Parabolic Trough Collector ", Center For Energy And Environmental Engineering National Institute Of Technology (INDIA), HAMIRPUR-177005, ; vol. 22, pp.1-2, July 2016.

[20] F. Vignola , F. Mavromatakis, J . Krumsick, "Performance of inverters", In Proceedings of the 37th ASES Annual Conference, San Diego, CA, USA, 3-8 May 2008.
[21] M. Mpholo, T. Nchaba, M. Monese, "Yield and performance analysis of the first grid connected solar farm at Moshoeshoe I International Airport", Lesotho. Renew Energy, vol. 81, pp.845-52, 2015.

[22] N.K. Kasim, A.F .Atwan, and F.M. Eliewi,"Improve the performance of solar modules by reflectors", Journal of Physics, The Sixth Scientific Conference, Renewable Energy and its Applications, Journal of Physics , pp.220-249, 2018. 